\title{
Caroli Disease: A Case Report Observed at the Cocody Teaching Hospital of Abidjan (Cote D'Ivoire)
}

\author{
A. Ouattara ${ }^{1 *}$, S. Koné1, E. Allah-Kouadio', D. Soro', A. W. Ndjitoyap1, E. Kouadio², \\ K. A. Kanga ${ }^{3}$, C. D. Fanou ${ }^{1}$, M. J. Lohoues-Kouacou'1, B. M. Camara ${ }^{1}$ \\ ${ }^{1}$ Service D’Hépato-Gastro Entérologie CHU Cocody, Abidjan, Côte D’Ivoire \\ ${ }^{2}$ Service De Pédiatrie Médicale, CHU Cocody, Abidjan, Côte D’Ivoire \\ ${ }^{3}$ Service D’Imagerie Médicale, CHU Cocody, Abidjan, Côte D’Ivoire \\ Email: ^drouattara2009@yahoo.fr
}

How to cite this paper: Ouattara, A., Koné, S., Allah-Kouadio, E., Soro, D., Ndjitoyap, A.W., Kouadio, E., Kanga, K.A., Fanou, C.D., Lohoues-Kouacou, M.J. and Camara, B.M. (2017) Caroli Disease: A Case Report Observed at the Cocody Teaching Hospital of Abidjan (Cote D'Ivoire). Open Journal of Gastroenterology, 7, 28-31.

http://dx.doi.org/10.4236/ojgas.2017.71004

Received: November 29, 2016

Accepted: January 19, 2017

Published: January 22, 2017

Copyright (๑) 2017 by authors and Scientific Research Publishing Inc. This work is licensed under the Creative Commons Attribution International License (CC BY 4.0).

http://creativecommons.org/licenses/by/4.0/

\begin{abstract}
Caroli disease is a rare affection. It's commonly associated to polycystic kidneys. We report a case of a nine-year-old girl. She was hospitalized at the pediatric unit of the Cocody Teaching Hospital for an intermittent fever. During the clinical examination, we found a likely cirrhotic hepatomegaly associated to an edematous-ascitic syndrome. Biological exams showed an infectious syndrome with a hyperleukocytosis at 13.000 per $\mathrm{mm}^{3}$, a hyperneutrophilia at 9.600 per $\mathrm{mm}^{3}$. Serological viral markers of B, C and D hepatitis were negative. We saw an intra-hepatic cystic picture at the liver CT-scan with a vascular lesion at his center called a "dot sign". The diagnosis of Caroli disease could be evocated.
\end{abstract}

\section{Keywords}

Carolisyndrom, Congenital Cystic Dilation, Cholangitis, Liver CT-Scan

\section{Introduction}

The involution of the ductal plate is the cause of many inherited diseases including Caroli disease [1]. It's a recessive autosomal affection characterized by a localized or a diffused cystic dilation of intra-hepatic bile ducts [2]. Clinical manifestations of the disease are variable, different from the childhood to the second or the third decade of life, generally diagnosed in adult people [3] [4] [5] [6]. When she is associated with a congenital hepatic fibrosis, she is called Caroli syndrome. In this case, clinical manifestations are those of congenital hepatic fibrosis including collateral venous circulation, esophageal varices and a spleno- 
megaly [3] [7]. However, there are some isolated cases [3] [7]. The prognosis factors depend on its complications: cholangitis, cirrhosis and cholangiocarcinoma [1] [4]. There are few cases of the Caroli disease reported in Africa [8]. We present here the first case in western Africa about a nine-year-old girl with cirrhosis.

\section{Case Report}

A nine-year-old girl was hospitalized at medical pediatric unit of Cocody Teaching Hospital of Abidjan (Ivory Cost) for an intermittent chronic fever which had reached 6 months earlier. There was no right upper quadrant of the abdomen pain, or digestive disorders. During physical examination, we observe a poor general state with a weight of 26 kilograms, a temperature of 38 degrees, an entire hepatomegaly, painless with a hard consistency, an irregular surface, a narrow lower edge associated with a mid-abundance ascite fluid and lower limbs edema. There were no collateral venous circulations, nor splenomegaly. Biological exams showed anhyperleucocytosis at 13.000 per $\mathrm{mm}^{3}$ with 9600 neutrophils, a C-reactive protein of $48 \mathrm{mg} / \mathrm{l}$ an hemoglobin level of $14 \mathrm{~g} / \mathrm{dl}$, a Platelets count of 260.000 per $\mathrm{mm}^{3}$, ASAT of $21 \mathrm{UI} / \mathrm{l}$ and ALAT of $6 \mathrm{UI} / \mathrm{l}$, total and conjugated bilirubin respectively of 6 and $1 \mathrm{mg} / \mathrm{l}$, Prothrombin rate of $60 \%$. The Protidogram shows an hypo albuminemia of $13.66 \mathrm{~g} / \mathrm{l}$, a polygonal hyper gammapathy of $24.29 \mathrm{~g} / \mathrm{l}$ and a betagamma block. Viral markers of B, C and D hepatitis were negatives. Autoimmune hepatitis markers were also negatives. The Alphafoetoprotein value was of $2.89 \mathrm{ng} / \mathrm{ml}$. There was no spontaneous ascite fluid infection. The upper digestive tract endoscopies do not found any hypertension sign. The abdominal ultrasonography revealed a hepatomegaly with many cystic dilations disseminated inside the liver parenchyma. We haves awed a "dot sign" at the CT-Scan. This aspect is in favor of a Caroli disease. After 1 month of an antibiotics treatment based on metronidazole, the child has been was lost of view.

\section{Discussion}

Caroli disease is a rare inherited affection, characterized by a localized or a diffuse cystic dilation of intra hepatic ducts due to a lack of involution of ductal plate [2]. Some genetic mutations about genes which regulate the formation of kidneys and bile ducts are responsible of embryonic malformations of ductal plate [9]. Many authors think that these mutations occur on the sixth chromosome. It's the PKHD1 gene implicated in the synthesis of fibrocystin, a protein involve in several abnormalities inside kidney and hepatic structure [10] [11] [12]. Therefore, this stasis of bile will favor infection syndromes which are the clinical manifestations of the disease. Like for our case, this typical clinical feature was described by different authors [4] [7]. At the end stage of the disease, cirrhosis including an hepatomegaly, an ascite and lower limbs edema could be associated like in the case of our patient [1] [13]. The diagnostic of this affection is based on radiologic exams [5] [7]. It could be evocated during an abdominal ultrasonography which shows cystic dilations inside the liver parenchyma. These 




Figure 1. Intra-hepatic picture center by a vascular structure called "dot sign" (arrow) evocated Caroli disease.

cystic dilations are generally diffuse like it was the case in for our patient [6]. Sometimes, this cystic dilation concerns only one part of the liver, mostly the left lobe [14]. The Resonance Magnetic Cholangiography is the best exam to show the communication cysts and biliary ducts, but wasn't realized for our patient [4] [5] [15]. For several authors, the "Dot sign" show as a cystic intra hepatic picture with a vascular lesion at his center at the CT-Scan (Figure 1) sign the diagnosis [1] [15]. However, the liver biopsy punction is the key exam to found a peri portal diffuse fibrosis, associated with a proliferation of bile ducts. The treatment is based on the treatment of chalongitis with antibiotics. The liver resection is indicated for localized forms with cirrhosis or not. While, the hepatic transplantation is indicated in diffuse forms [1] [6] [7] [15] [16] [17].

\section{Conclusion}

Caroli disease is a rare autosomic inherited affection which should be evocated in all children with an intermittent infectious syndrome associated to a hepatomegaly. The presence of a "dot sign" at the liver CT-Scan is in favor of this diagnosis.

\section{References}

[1] Karim, A.S. (2004) Caroli's Disease. Indian Pediatrics, 41, 848-850.

[2] Bockhorn, M., Malago, M., Lang, H., Nadalin, S., Paul, A., Saner, F., et al. (2006) The Role of Surgery in Caroli's Disease. Journal of the American College of Surgeons, 202, 928-932. https://doi.org/10.1016/j.jamcollsurg.2006.02.021

[3] Steinbruck, K., Enne, M., Martinho, J.M., Fernandes, R. and Pacheco-Moreira, L.F. (2011) Living Donor Liver Transplantation for Caroli’s Disease: A Report of Two 
Cases. ISRN Surgery, 2011, Article ID: 106487. https://doi.org/10.5402/2011/106487

[4] Iancu, C., Bodea, R., Muresan, T., Iancu, D., Boruah, P. and Al Hajjar, N. (2010) Diffuse Form of Caroli's Disease: Therapeutical Approach in a Female Patient with Recurrent Cholangitis. The Journal of Gastrointestinal and Liver Diseases, 19, 457 460.

[5] Ananthakrishnan, A.N. and Saeian, K. (2007) Caroli's Disease: Identification and Treatment Strategy. Current Gastroenterology Reports, 9, 151-155. https://doi.org/10.1007/s11894-007-0010-7

[6] Giovanardi, R.O. (2003) Monolobar Caroli's Disease in an Adult. Case Report. Hepatogastroenterology, 50, 2185-2187.

[7] Yonem, O. and Bayraktar, Y. (2007) Clinical Characteristics of Caroli's Disease . World Journal of Gastroenterology, 13, 1930-1933. https://doi.org/10.3748/wjg.v13.i13.1930

[8] Last, R.D., Hill, J.M., Roach, M., et al. (2006) Congenital Dilatation of the Large and Segmental Intrahepatic Bile Ducts (Caroli's Disease) in Two Golden Retriever Littermates. Journal of the South African Veterinary Association, 77, 210-214. https://doi.org/10.4102/jsava.v77i4.379

[9] Levy, A.D., Rohrmann, J.R., Murakat, L.A., et al. (2002) Caroli's Disease: Radiological Spectrum with Pathologic Correlation. American Journal of Roentgenology, 179, 1053-1057. https://doi.org/10.2214/ajr.179.4.1791053

[10] Srinath, A. and Shneider, B.L. (2012) Congenital Hepatic Fibrosis and Autosomal Recessive Polycystic Kidney Disease. Journal of Pediatric Gastroenterology and Nutrition, 54, 580-587. https://doi.org/10.1097/MPG.0b013e31824711b7

[11] Gunay-Aygun, M., Font-Montgomery, E., Lukose, L., et al. (2012) Characteristics of Congenital Hepatic Fibrosis in a Large Cohort of Patients With Autosomal Recessive Polycystic Kidney Disease. Gastroenterology, 144, 112-121. https://doi.org/10.1053/j.gastro.2012.09.056

[12] Guay-Woodford, L.M. (2014) Autosomal Recessive Polycystic Kidney Disease: The Prototype of the Hepato-Renal Fibrocystic Diseases. Journal of Pediatric Genetics, 3, 89-101.

[13] Milanga, M., Yamada, H., Ishiharajima, S., Yamanaka, N., Asano, G., Fukuda, Y., et al. (1990) Caroli's Disease Associated with Liver Cirrhosis. An Autopsy Case. Journal of Nippon Medical School, 57, 486-492. https://doi.org/10.1272/jnms1923.57.486

[14] Madjov, R., Chervenkov, P., Madjova, V. and Balev, B. (2005) Caroli's Disease. Report of 5 Cases and Review of Literature. Hepatogastroenterology, 52, 606-609.

[15] Acioli, M.L., Costa, L.R. and de Miranda Henriques, M.S. (2014) Diffuse Caroli's Disease with Atypical Presentation: A Case Report. Annals of Gastroenterology, 27, 79-81.

[16] Kassahun, W.T., Kahn, T., Wittekind, C., Mossner, J., Caca, K., Hauss, J., et al. (2005) Caroli's Disease: Liver Resection and Liver Transplantation. Experience in 33 Patients. Surgery, 138, 888-898. https://doi.org/10.1016/j.surg.2005.05.002

[17] Wang, Z.X., Yan, L.N., Li, B., Zeng, Y., Wen, T.F. and Wang, W.T. (2008) Orthotopic Liver Transplantation for Patients with Caroli's Disease. Hepatobiliary \& Pancreatic Diseases International, 7, 97-100. 
Submit or recommend next manuscript to SCIRP and we will provide best service for you:

Accepting pre-submission inquiries through Email, Facebook, LinkedIn, Twitter, etc. A wide selection of journals (inclusive of 9 subjects, more than 200 journals)

Providing 24-hour high-quality service

User-friendly online submission system

Fair and swift peer-review system

Efficient typesetting and proofreading procedure

Display of the result of downloads and visits, as well as the number of cited articles Maximum dissemination of your research work

Submit your manuscript at: http://papersubmission.scirp.org/

Or contact ojgas@scirp.org 